\title{
SELF IMAGE CONGRUITY AND CUSTOMER PERCEIVED SQ ON IMPACT SATISFACTION ON REPURCHASE INTENTION
}

\author{
Bob Foster \\ University of Informatics and Business Indonesia \\ bobriset@unibi.ac.id
}

\begin{abstract}
The purpose of this research is to find out how the effect of Self Image Congruity and Customer Perceived Service Quality on Customer satisfaction has an impact on Repurchase Intention. In this study, the author took the object on the product at Alisha Fancy Shop. Based on the calculations performed, the sample used in this study amounted to 100 respondent. Analysis is carried out by the path analysis method. To clarify the variables studied, from what was formulated in the description above, that the subject matter under study is Self Image Congruity (X1), Customer Perceived Service Quality (X2), Customer satisfaction (Y), and Repurchase Intention (Z). From the results, there is a study which found that the Self Image Congruity and Customer Perceived Service Quality variables simultaneously have a significant effect on Customer satisfaction; partially the Self Image Congruity and Customer Perceived Service Quality variables have a significant effect on Customer satisfaction with a positive direction. In addition, the Self Image Congruity, Customer Perceived Service Quality, and Customer satisfaction variables also have an influence on Repurchase Intention simultaneously; partially the Self Image Congruity and Customer satisfaction variables have a significant effect on Repurchase Intention in a positive direction, while the Customer Perceived Service Quality variable is not significant effect on Repurchase Intention. Indirectly the Self Image Congruity variable and the Customer Perceived Service Quality have an influence with a positive direction towards Repurchase Intention.
\end{abstract}

Keywords: Self Image Congruity, Customer Perceived Service Quality, Customer, Repurchase Intention

\section{Introduction}

Based on data released by the Central Statistics Agency (BPS), Indonesia's economic growth tends to be stable at around 5 percent in the last 3 years and has an increasing trend, although not significant. But if studied more deeply, the structure of Indonesia's economic growth actually experienced a significant and most visible improvement was investment and export growth, which grew 6.15 and 9.09 percent in 2017, compared to the growth of these two components in 2016 which was only 4,47 and -1.57 percent. Meanwhile, related to growth in household consumption, the Indonesian government has managed to keep growth at around 5 percent. This condition can be realized because the government is able to keep the inflation rate below 4 percent in accordance with the APBN target and is still within the target range of Bank Indonesia, which is 2.5 - 4.5 percent. The majority of provinces in Indonesia experience economic growth above the national average, while only a few provinces experience economic growth below the national average. Meanwhile, in the Asian perspective Indonesia's average economic growth in the last 3 years is still better than Thailand, Hong Kong, South Korea and Singapore.

Uneven economic growth in each province, on Java Island 5.7\%, is more than the national average. Other islands are above the national average such as Sulawesi $6.7 \%$ and Papua and Maluku due to infrastructure development. But 
Sumatra, Kalimantan, is still below the average because it depends on commodities. The economy of West Java, which is measured based on the amount of Gross Regional Domestic Product (GRDP) at current prices, Quarter III-2017, reached Rp 459.13 trillion and on the basis of constant prices in 2010 reached $\mathrm{Rp} 342.78$ trillion. From the lift, West Java's economy grew by 5.19 or above the national growth average. The economy of West Java is supported by 3 main sectors, namely the Processing Industry with a market share of $43.03 \%$, trading with a Share of $15.21 \%$ and Agriculture with a share of $8.71 \%$. In addition, the province of West Java is one of the main investment destinations with a national share of Foreign Investment (PMA) reaching 20.4\% and Domestic Investment (PMDN) reaching $14.1 \%$.

The Indonesian government is currently intensifying its creative economy. Change and innovation are very excited about the process. Successfully completed programs require commitments made based on an interesting and emotional vision that is successfully completed with the program (Sariningsih, 2017). The Creative Economy Agency (Bekraf) as a body that handles the creative economy in Indonesia has a target to increase the competitiveness of the national creative economy. The numbers of creative economic sectors that are developing rapidly and have high potential to be developed are the culinary, fashion and craft (handicraft) sectors. Fashion ranks second after culinary from 15 creative economy sectors with percentage gain of 18.5 percent. Currently the development of Muslim fashion in Indonesia is very fast, the impact is the emergence of Muslim clothing communities and one of them is a hijab user. The hijab industry belongs to the creative industry in the fashion field. According to
Djaslim (2010) the reason for the decent hijab industry to be developed is first, being able to make a significant contribution in the economic field and create a positive business climate in the country. Second, it can build an image of the identity of the Indonesian people in the eyes of the world and mostly based on renewable resources. Third, create innovation and creativity which is a nation's competitive advantage and has a positive social impact. The domestic market is quite large with a growing middle class that has an important role to enhance the industry and strengthen the purchasing power of consumer goods (Ngoc, 2016).

Management as an activity carried out by the company to carry out its functions in order to realize the objectives that have been set, therefore to achieve these objectives, the company must carry out activities such as planning, organizing, directing, and supervising effectively and efficiently. Management is said to be science and art regulates the process of utilizing human resources and other sources to achieve a certain goal. The role of management is very large on the success of a business enterprise. Management is one of the important and essential sciences needed by every company. Management is a privilege in dealing with time and human relations problems when they arise in organizations or companies. Lots of experts express differing opinions, but in principle, they have the same intent and purpose, according to the author, management is a process of direction from the provision of facilities to the work of people organized in the organization. Management is also an activity that is based on science and art to achieve predetermined goals with the help of others in achieving organizational or group goals, and is also a process of a series of activities so that the 
implementation of work can take place effectively and efficiently. Marketing is one of the main activities that need to be done by a company whether it is a company of goods or services in an effort to gain profits and to maintain the viability of the business.

Some marketing experts such as John W. Mullins and Orville C. Walker (2013: 14) suggest marketing is a social process that involves activities needed to enable individuals and organizations to get what they need and want through exchanges with others and to develop exchange relations sustainable. Whereas according to Kotler and Armstrong (2015: 30) marketing is a process where companies create value for customers and build strong relationships with customers to get value from customers in return. Furthermore Kotler and Keller (2016) marketing is about identifying and meeting human and social needs. One of the shortest definitions of good marketing is to fulfill needs profitably.

Referring to definitions previously stated by John W. Mullins and Orville C. Walker (2013: 14); Kotler and Armstrong (2015: 30); Kotler and Keller (2016), the authors conclude that marketing management is an art and science in choosing target markets designed to create and maintain profitable exchanges to achieve company goals, namely profile and sustainability. In marketing, interaction is needed between the elements in it to achieve the stated goals.

Image is one of the bases used by consumers to determine the compatibility between the personalities possessed with the product offered. Selfimage congruity is the level of conformity between the consumer's selfimage and the image of the product or brand ( $\mathrm{Su}$ and Reynolds, 2017). According to Widjiono and Japarianto
(2015) states that the self-image are possessed by each individual in the result of the development of the background and experience of the individual. Individuals in essence will certainly choose goods or services that are in accordance with their image. In line with what was stated by Hanggara and Brahmana (2015); Hartini (2012) then self-image congruity shows the level at which a consumer sees themselves as individuals who are in accordance with the purpose of the product produced and allows consumers to express themselves according to the brand that will be purchased and used.

In Anggara and Brahmana (2015) argue that self-image congruity has 4 (four) dimensions, namely: actual selfcongruity, actual social self-congruity, ideal self-congruity, and ideal social self-congruity. 1) Actual self-congruity, self-concept that has been shown by individuals at this time. This selfconcept is related to how the individual actually values himself through attitudes and behaviors that have been reflected in his daily life personally. 2) Actual social self-congruity, a self-concept that has been manifested by individuals in their environment in an effort to actualize themselves. With this self-concept, individuals can find out how the actual environmental assessment of the selfconcept they have shown 3) Ideal selfcongruity, the concept of self that actually wants to be achieved by individuals in their personal lives or it can also be called a self-concept that is actually aspired by individuals to perfect their actual self-concept. 4) Ideal social self-congruity, self-concept that encourages individuals to show their ideal side. With self-concept, someone wants how the environment should see itself.

According to Sreejesh et al. (2015) functional congruity is the difference between customer perceptions of 
product attributes before making their purchase and evaluation after purchase. Sreejesh et al. (2015) states that functional congruity is the difference between customer perceptions of product or service attributes before making their purchase and evaluation after purchase. Consumers want products not for physical products themselves, but for the benefits they get from using the products they have bought (Klipfel et al, 2014). Functional congruity is a match between consumer trust related to the brand's utilitarian aspects, such as performance attributes and consumers as references. Referrals, like the ideal aspect, are the criteria used to evaluate the dimensions of actual brand performance. Consumers have a standard or reference as their ideal that is used to assess the goodness of perceived features. functional congruity is conceptualized as a variation of attitude models through evaluation of utilitarian attributes (Kumar and Nayak, 2014). Utilitarian attributes refer to perceived characteristics related to comfort, customer service, performance or quality and reliability. Functional congruity has important benefits to the attitude of customers and will affect the purchase behavior. The quality of brand relationships between consumers and brands or consumers' functional suitability, which reflects the extent to which their positive assessment of the functional brand attributes such as conformity to their needs (Wang et al, 2015). According to Kang et al. (2012), functional congruity is defined as the expectations and experiences of consumers of products / services, using measurements of six indicators including (1) location, (2) clean, (3) quality, (4) seat, (5) menu, ( 6) staff, (7) interior, and (8) price.

In Widjiono and Japarianto (2015) suggest that perceived service quality is the basis of the formation of a quality and can be used to measure customer satisfaction. While on the other hand Tjiptono Tjiptono and Gregorius (2016) in his book states that perceived quality is the image and reputation of the product and the company's responsibility towards it. Bitner \& Zeithaml in Widjiono and Japarianto (2015) states that a customer in assessing a product used will be based on at least three categories, namely the quality of the interaction, the quality of the physical environment, and the quality of results. The quality of interaction is quality that is closely related to how the service process is delivered, which is seen from the process of interaction between service provider staff and their customers. The quality of the physical environment is a quality that exists in the environment in which the service process occurs. The quality of the results is what the customer gets, when the process of producing service and the interaction between the customer and the service provider is complete.

According to Zeithaml in Sudjianto and Japarianto (2017) services such as those perceived by consumers can be defined as the extent of differences between consumer expectations or their desires and perceptions. The implementation of service quality has become a strategy for several industries. Service quality is one strategy in achieving customer satisfaction. The success of the company in providing quality services to its customers, achieving high market share, and increasing the company's profit are largely determined by the approach used.

In its development the dimensions of perceived service quality underwent several changes and developments. The perceived service quality that will be used in this study has 5 dimensions, namely: 1) Tangible, Tangible is part of the dimensions of service quality and 
includes several elements of the company. This dimension describes the physical form and service that will be accepted by consumers. There are at least four attributes of physical evidence including modern equipment, attractive visual facilities, neat and professional employees, and visual appeal. 2) Reliability, Reliability the company's ability to provide reliable and accurate services from the first time without making any mistakes and delivering services in accordance with the agreed time. At least five attributes of reliability include providing services in accordance with the promised, reliable in handling customer service issues, delivering services properly, delivering services in accordance with the promised time, and keeping records or documents without errors. 3) Responsiveness, Responsiveness relates to the willingness and ability of employees to provide services quickly. This dimension emphasizes attention and accuracy when dealing with customer requests, statements and complaints. There are at least four attributes of responsiveness including informing customers about the certainty of the time of delivery of services, prompt or fast service for customers, willingness to help customers, and readiness to respond to customer requests. 4) Assurance, Assurance can relate to the behavior of employees who are able to foster customer trust in the company and the company can create a sense of security for customers. The guarantee is that employees are always polite and master the knowledge and skills needed to handle every customer complaint. At least there are four attributes of assurance, including employees who foster customer trust, make customers feel safe when making transactions, employees are consistently polite, and employees are able to answer every customer complaint. 5) Empathy, Empathy is a concern and concern and means that the company understands customer problems and acts in the interests of customers, and gives personal attention to customers and has comfortable operating hours. At least there are five attributes of Empathy, among them are giving individual attention to customers, employees are able to treat customers attentively, truly prioritize the interests of employees, employees who understand the needs of employees, and convenient operating time.

According to some experts such as Daryanto and Setyobudi (2014) said consumer satisfaction is about emotional assessment of consumers after consumers use products where consumer expectations and needs are met. Whereas Kotler and Armstrong (2015: 35) Customer satisfaction is which product is considered a product that is in accordance with the expectations of the buyer. If the new product is far from expectations, the customer is not satisfied. If it is in line with expectations, the customer is satisfied. If you expect to exceed expectations, customers are very happy to be satisfied. Salain, Tjiptono and Gregorius (2016) also expressed satisfaction arising after gaining experience using products. Furthermore Kotler and Keller (2016: 153) state that satisfaction is a feeling of pleasure or disappointment that arises after comparing the performance (results) of the product that is thought of the expected performance (or results). Satisfaction level is one of the three general levels of satisfaction. Then researchers consider that consumer satisfaction

Therefore, it is thought, researchers concluded that consumer satisfaction is a feeling of pleasure or satisfaction that consumers receive from the experience gained from the products offered by the company with expectations and needs 
that can be met. If the expectation value is equal to the value of reality, the customer will be satisfied, if the expectation value is smaller than the value of consideration, the customer will be satisfied. However, if expectations are greater than the value of realization, the customer will feel satisfied. According to Tjiptono and Gregorius (2016) states that each company requires a combination strategy in order to realize customer satisfaction, therefore the strategy determined is an offensive strategy and defensive strategy. By knowing the feelings of many consumers after making a purchase and using the product, then consider whether the product and service are in line with expectations due to the basis of satisfaction is a brief experience of consumers who use products in accordance with agreed requirements (Chandio, 2015).

Consumer satisfaction is measured by how much consumer expectations about products and services are in accordance with the actual product and service performance. Large companies, especially consumer-oriented, will routinely conduct research on customer satisfaction. Some methods applied to measure consumer satisfaction according to Kotler \& Keller (2016) include: 1) System of complaints and suggestions, the Company makes it easy for consumers to submit suggestions and complaints. For example, is using the suggestion box. 2) Customer satisfaction surveys, companies need to conduct research or surveys every period by distributing questionnaires, in this way the company will get responses and feedback directly from customers. 3) Ghost shopper, the Company hires people as ghost shopper who will report the acquisition of high and low scores from their experience shopping for products from competing companies. From here the company can find out how sales staff handle the situation or situation properly if there are complaints from consumers. 4) Analysis of lost customers, Companies should contact customers who have switched to other suppliers to learn why this happened.

The purpose of determining customer needs is to form a list of all important quality dimensions in describing goods or services. Knowing the quality dimension is very important, so it will find out how customers define the quality of the goods or services they receive. Only by understanding the quality dimension, will be able to develop measures to assess this quality dimension. So it is very important for each company to identify its goods and services. Analyzing goods and services will provide a comprehensive picture of this dimension. In order for companies to excel or even just to survive in competition, companies need a new philosophy. Companies that are philosophical and have insightful customers will excel in competition, because they can provide better value to customers than their competitors. They will also find it easier to get customers, not only proficient at making products, engineering products, and engineering markets.

In principle, there are three keys to providing quality services for customers, namely: 1) The ability to understand the needs and desires of customers. 2) Database development is more accurate than competitors. 3) Use of information obtained from market research in a strategic framework. Quality and service are the means to achieve customer satisfaction. The overall goal of the company is not to produce quality products or services or provide excellent service. The company's main goal is to produce satisfied and loyal customers who will continue to establish business with the company. Therefore, providing high quality and excellent service is a 
must if the company wants to achieve the main goal of satisfied and loyal customers.

Repurchase intention is the impact of purchases made by consumers. Repurchase intention is the activity of buying back a product twice or more. In repurchase there are two characteristics, namely intention and behavior, in repurchasing there is a close relationship with consumer attitudes toward previous behavior. some studies have found that satisfaction is not directly related to repurchase. but on the other hand there is also research that shows that satisfaction encourages intensive and intensive encouraging behavior therefore repurchasing can be said to be one indicator of satisfaction and also the effect of purchases. Some experts like Nurhayati and Wahyu (2012: 53); Oetomo \& Nugraheni (2012); Thamrin and Francis (2012); Hendarsono and Sugiharto (2013); Gholamreza Asadian (2015: 3) has expressed the understanding of Repurchase Intention. Therefore, according to researchers, Repurchase Intention is the interest in buying based on the buying experience that has been done in the past, and of course the purchase is done more than once because consumers are satisfied with the products offered by the company.

Nurhayati and Wahyu (2012: 53) is the willingness and actions of consumers to repurchase a product, because of the satisfaction received according to the desired of a product. Brands that are inherent in the customer's heart will cause the customer to continue purchasing or repurchasing. Oetomo \& Nugraheni (2012) The interest in repurchasing is basically customer behavior where customers respond positively to the quality of service of a company and intend to revisit or reconsume the company's products.
Thamrin and Francis (2012) repurchase interest is the purchase interest based on the buying experience that has been done in the past. The high interest in repurchasing reflects a high level of satisfaction from consumers when deciding to adopt a product. Hendarsono and Sugiharto (2013) the notion of repurchasing interest is customer behavior where the customer responds positively to what has been given by a company and is interested in making a return visit or re-consuming the company's products.

According to researchers Repurchase Intention is the interest in buying based on the buying experience that has been done in the past, and of course purchases are made more than once because consumers are satisfied with the products offered by the company. According to Kotler and Armstrong (2015) the main factors that influence someone's interest to make a repeat purchase, namely: 1) Factor Culture, culture and social class can influence someone's interest in making a purchase. Consumers have perceptions, desires and behaviors learned from childhood, so that they will eventually form different perceptions in each consumer. Factors of nationality, religion, racial group and geographical area also influence each individual. 2) Psychological Factors, Includes individual learning experiences about past events, as well as the influence of individual attitudes and beliefs. Learning experience can be defined as a change in behavior due to previous experience. The emergence of consumer interest to make repeat purchases is strongly influenced by individual learning experiences and consumer learning experiences that will determine buying actions and decision making. 4) Personal factors, personality, age, work, economic situation and lifestyle of the consumer itself will influence the 
perception and decision making in buying. Therefore, the role of restaurants is important in providing good service to consumers. These personal factors include self-concept. Self-concept can be defined as the way we see ourselves and in a certain time as a picture of the wages we think. In relation to repurchasing interest, restaurants need to create a situation that consumers expect. Similarly, providing and serving consumers with products that are in accordance with what consumers expect. 5) Social Factors, including small reference group factors. Anutan group is defined as a group of people who influence attitudes, opinions, norms and consumer behavior. Anutan group is a collection of families, groups or certain people. In analyzing repurchase interest, family factors act as decision makers, initiative makers, influence in purchasing decisions, determinants of what is bought, who makes purchases and who becomes a user. The influence of the reference group on repurchasing interests includes determining the products and brands they use that are in accordance with the group's aspirations. The effectiveness of the effect of repurchase intention from the annex group is very dependent on the quality of the production and the information available to the consumer.

Quoted by Basrah and Samsul (2012: 7), there are four dimensions of repurchase interest, namely transactional interest, namely the tendency of consumers to always repurchase the products they have consumed. Referential interest is the willingness of consumers to recommend products that have been consumed by others. Preferential interest is consumer behavior that makes the product that has been consumed as the main choice. Explorative interest is the desire of consumers to always look for information about the products they are interested in.
In this study, the author took the object on the product at Alisha Fancy Shop. According to Sugiyono (2017) what is meant by Research methods is basically a scientific way to obtain data with specific purposes and uses. While according to Danang Sunyoto (2016: 19) is as a research method will determine the sequences of data analysis processes that will be presented systematically. From this understanding it can be said that the research method is a scientific method and procedure that is systematic and organized to obtain data to achieve certain goals and procedures for how a study is carried out. The method used in this research is descriptive verification method. Descriptive verification method aims to describe the truth or absence of the facts and explain the relationship between the variables studied by blunting data, processing, analyzing, and interpreting data in testing hypotheses.

Alisha Fancy Shop is a hijab shop with Alisha hijab brand or the latest is Geulis and other brands. In 2016, Alisha was more active in using social media with the aim of introducing Alisha's new products and providing information to consumers. To note that Alisha Fancy Shop is located on Jalan Salendro and has several branches in the city of Bandung. But in 2017 Alisha's sales turnover decreased by 30 percent from the previous year. Until now, the number of visitors at Alisha Fancy Shop tends to fluctuate, but visitors who know Alisha's information from social media, especially Instagram, only help increase sales by less than 10 percent. Even various businesses have been carried out both online and offline promotions. Therefore, the researchers in this study 
wanted to find out how the effect of Self Image Congruity and Customer Perceived Service Quality on Customer satisfaction had an impact on Repurchase Intention. From the identification of these problems, the next discussion in this study is only limited to the object under study, namely Alisha Fancy Shop Bandung and respondents from this study are consumers of Alisha Fancy Shop Bandung.

\section{Method}

The sampling technique used by the author is a non-probability sampling technique. According to Sugiyono (2017: 122) non probability sampling is a sampling technique that does not provide the same opportunity or opportunity for each element or member of the population to be selected as a sample. The reason for selecting the sample using purposive sampling is because not all samples have criteria that are in accordance with the authors specify. For example, as for the criteria that the authors wrote, one of them is all consumers who have bought and repurchased. Based on the calculations made, the sample used in this study was 100 people. The research method used in this study is to use quantitative methods. The analysis is done by validity test, reliability test and on data sourced from the primary data (questionnaire) that has been shared. Then the results of this questionnaire will produce data to be analyzed by the path analysis method. Data processing is done using SPSS 24.00. To clarify the variables studied, from what was formulated in the description above, that the subject matter under study is Self Image Congruity (X1), Customer Perceived Service Quality (X2), Customer satisfaction (Y), and Repurchase Intention (Z).

\section{Result and Discussion}

Path Analysis Results

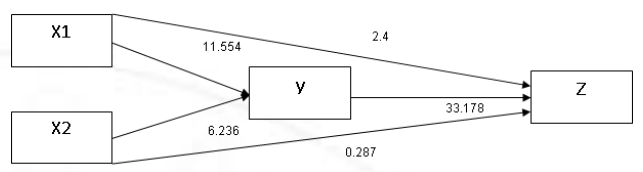

Figure 2. Path Analysis Results

The research path diagram has the following structural equation:

Sub structure one:

$$
\begin{aligned}
& \mathrm{Y}=\rho \mathrm{ZX} 1+\rho \mathrm{ZX} 2+\mathrm{e} 1 \\
& \mathrm{Y}=11.554 \mathrm{X} 1+6.236 \mathrm{X} 2+
\end{aligned}
$$

0.483

Sub structure two:

$$
\begin{aligned}
& \mathrm{Z}=\rho \mathrm{YX} 1+\rho \mathrm{YX} 2+\rho \mathrm{YZ}+\mathrm{e} 2 \\
& \mathrm{Z}=2.400 \mathrm{X} 1+0.287 \mathrm{X} 2+ \\
& 33.178 \mathrm{Y}+0.455
\end{aligned}
$$

Based on the results of the analysis of calculations, the influence between variables from substructure one and substructure two is Self Image Congruity (X1) has a positive effect on Customer sarisfaction (Y) of 11,554 with a significance level of 0,000 , meaning that the product is more appropriate to the customer's image or in accordance with consumer needs, consumers will feel more satisfied. Customer Perceived Service Quality (X2) has a positive effect on Customer sarisfaction $(\mathrm{Y})$ of 6.236 with a significance level of 0.000 , meaning that if what consumers perceive is related to service quality is appropriate or even better than perceived then consumers will feel or be satisfied. Self Image Congruity (X1) has a positive effect on Repurchase Intention (Z) directly at 2,400 with a significance level of 0.018 , meaning that the more suitable the product is produced by the company with consumer image or according to consumer needs, the consumer will make a repeat purchase. The Customer Perceived Service Quality (X2) does not 
affect Repurchase Intention (Z) directly, meaning that in this study it is not consumer perceptions about the quality of services that affect re-purchases, of course there are other factors that cause consumers to repurchase.

Customer sarisfaction (Y) has a positive effect on Repurchase Intention (Z) directly amounting to 33,178 with a significance level of 0,000 , meaning that the higher consumer satisfaction with products offered by the company, the repurchase can be increased. The indirect effect of Self Image Congruity (X1) on Repurchase Intention (Z) is $(11,554 \times 33,178)$ that is equal to 383,339 , meaning that the more suitable the product produced by the consumer image or according to consumer needs, the consumer will feel more satisfied and if the consumer has satisfied, they will make a repeat purchase. The indirect influence of the Customer Perceived Service Quality (X2) on Repurchase Intention $(\mathrm{Z})$ is $(6,236 \mathrm{x}$ 33,178 ) that is equal to 206,898 , meaning if what consumers perceive is related to service quality is appropriate or even better than perceived then consumers will feel or be satisfied and if consumers are satisfied, they will make a repeat purchase.

From this study it was found that Self Image Congruity and Customer Perceived Service Quality simultaneously had an influence on Customer satisfaction. The value of significance produced was less than 0.05 . The magnitude of the effect of Self Image Congruity (X1) and Customer Perceived Service Quality (X2) on Customer satisfaction (Y) is $76.7 \%$ while $23.3 \%$ is influenced by other factors outside the variables studied. This means that the company in carrying out its business activities must pay attention to Self Image Congruity and Customer Perceived Service Quality so that Customer satisfaction can be achieved. The products produced must be in accordance with the Self Image Congruity and services in accordance with the Customer Perceived Service Quality, resulting in an increase in satisfaction.

From the results of the study indicate that there is a significant influence between Self Image Congruity towards Customer satisfaction with positive direction. The significance value produced is less than 0.05 , which is equal to 0,000 . These results have implications that customers who come to Alisha Fancy Shop to buy products in the form of hijab due to the compatibility of the personality between the individual and the product offered. A positive personality or self-image can lead to satisfaction at Alisha Fancy Shop. Therefore, in creating or producing a product to meet consumer needs must pay attention to the needs and characteristics of the target market well, because if not satisfaction will never be achieved.

The results of the study show that there is a significant influence between the Customer Perceived Service Quality and Customer satisfaction in a positive direction. The significance value produced is less than 0.05 , which is equal to 0,000 . This result has implications that the perception of good customer service quality will be able to influence customer satisfaction. A good perception of service quality can reflect if customers are satisfied with the hijab product sold by Alisha Fancy Shop, because the perception of the quality of service at Alisha Fancy Shop can arise due to self-assessment. When a person has expectations or perceptions of the service and turns out that the service is appropriate, they will be satisfied, if higher services are provided than expected, they will feel very satisfied, 
but if the services provided are far below those expected, they will feel they are not satisfied or very dissatisfied.

From the results of this study it was found that Self Image Congruity, Customer Perceived Service Quality and Customer Sarisfaction simultaneously had an influence on Repurchase Intention. The significance value produced is less than 0.05 . The magnitude of the influence of Self Image Congruity $\left(\mathrm{X}_{1}\right)$. Customer Perceived Service Quality (X2), and Customer sarisfaction (Y) on Repurchase Intention (Z) are $79.7 \%$ while $20.7 \%$ are influenced by other factors outside the variables studied. This result has implications that consumers as buyers of products produced by Alisha Fancy Shop must obtain products that are as expected and services that are in line with what has been perceived, because with the fulfillment of this component, satisfaction will emerge. Satisfaction as a result of fulfilling the needs and perceptions received by consumers will cause consumers to repurchase Alisha Fancy Shop products, because consumers assume that the products offered by Alisha Fancy Shop have been able to fulfill what they want and therefore there is no reason for them not make a repeat purchase. But of course the components that have been matched must always be improved both in terms of product and service because if there is a decline, consumers who have made the purchase will feel disappointed and certainly will have an impact on the emergence of dissatisfaction and will not make repeat purchases, and if this happens it will have an impact on losses for Alisha Fancy Shop because it will cause a decrease in profitability.

The results of the study show that there is an indirect effect between Self Image Congruity towards Repurchase Intention in a positive direction. The significance value produced is smaller than 0.05 , which is equal to 0.018 . These results have implications that customers who come to Alisha Fancy Shop to buy products in the form of hijab due to the compatibility of the personality between the individual and the product offered. A positive personality or self-image of a person can lead to a Repurchase Intention at Alisha Fancy Shop. Therefore, in creating or producing a product to meet consumer needs must pay attention to the needs and characteristics of the target market well.

The results of the study show that there is no indirect influence between the Customer Perceived Service Quality on Repurchase Intention. Where the significance value generated is greater than 0.05 , which is equal to 0.775 . This result has implications that in this study with the Alisha Fancy Shop object, the Customer Perceived Service Quality variable does not have an effect on Repurchase Intention. Consumer perspective on quality has no effect on repurchase, this is because consumers do not consider service quality factors, but other factors such as product suitability with self-image and other variables not examined in this study.

The results of the study show that there is a significant influence between Customer satisfaction and Repurchase Intention in a positive direction. The significance value produced is less than 0.05 , which is equal to 0,000 . Getting a customer is a difficult thing, but even more difficult is maintaining the customer. that being able to create customer satisfaction at Alisha Fancy Shop will affect the occurrence of Repurchase Intention. In addition, customer satisfaction is a material review of how much they enjoy shopping at Alisha Fancy Shop, 
knowing this will find out where the repairs must be improved.

\section{Conclusion}

From the results of the research and discussion conducted, this study found that simultaneously the Self Image Congruity and Customer Perceived Service Quality variables had a significant effect on Customer satisfaction. Partially the Self Image Congruity and Customer Perceived Service Quality variables have a significant effect on Customer satisfaction with a positive direction. In addition, the Self Image Congruity, Customer Perceived Service Quality, and Customer satisfaction variables also have an influence on Repurchase Intention simultaneously; partially the Self Image Congruity and Customer satisfaction variables have a significant effect on Repurchase Intention in a positive direction, while the Customer Perceived Service Quality variable is not significant effect on Repurchase Intention. Indirectly the Self Image Congruity variable and the Customer Perceived Service Quality have an influence with a positive direction towards Repurchase Intention. Based on the conclusions of the study, the suggestions the authors give so the company in its activities always pays attention to customer satisfaction. Satisfaction is an important element so that a consumer becomes loyal to the company's products for that, control of quality, service when buying and retiring, and conformity to consumer needs, if the company has consistency in the product and has the ability to know the needs of consumers, satisfaction will be achieved and repeat purchase will occur.

\section{References}

Chandio, A., \& Javed. (2015). Pemodelan hubungan yang tidak jelas pengembangan karir dengan ketidakpuasan kerja, stres kerja dan karyawan terhadap turnover intention. International Research Journal of Arts \& Humanities Vol. 41.ISSN: 1016- 9342.

Daryanto., I., S. (2014). Konsumen dan pelayanan prima. Malang: Gaya Media.

Gholamreza, A. (2015). Study of percieved image of origin country on percieved value and repurchase intention among korean appliances. Korea : VISI J Akademik.

Hanggara, V., \& Brahmana, R. K. M. R. (2015). Pengaruh brand personality the javana terhadap purchase intention melalui pendekatan self-image congruence. Jurnal Strategi Pemasaran Vol 3, No 12015.

Hartini, S. (2012). Perilaku pembelian smartphone: analisis brand equity dan brand attachment. Jurnal Mitra Ekonomi Dan Manajemen Bisnis. Vol 3, No 1, Hal: 75 - 86. Universitas Airlangga Surabaya

Hendarsono, G \& Sugiharto, S. (2013). Analisis pengaruh experiental marketing terhadap minat beli ulang konsumen cafe buntos 99 sidoarjo. Jurnal Manajemen Pemasaran Universitas Kristen Petra, Vol.1 No.2 hal 1-8.

Kang, J., Tang, L., \& Lee, J. Y. (2012). Self congruity and functional congruity in brand loyality. Journal Of Hospitality \& Tourism Research, 39 (1), 105-131.

Kotler, P., \& Amstrong. (2015). Principle of marketing (15rd ed.). New Jersey: Prentice-Hall Published. 
Kotler, P., \& Kevin, L. K. (2016). Marketing management (15rd ed.). Pearson Education,Inc.

Klipfel, A. L., Barclay, A. C., Bockorney, K. M. (2014). Self congruity : a determinant of brand personality. Journal Of Marketing Development And Competitiveness 8 (3).

Kumar, V., Nayak, J. K. (2014). Destination personality : scale development and validation. Journal Of Hospitality \& Tourism Research December 2014.

Mullins, J. W., Walker, Jr., Orville, C. (2013). Marketing management: a strategic decision-making approach (13rd ed.). McGrawHill International Edition.

Nurhayati., Wahyu, W. M. (2012). Analisis faktor-faktor yang memprngaruhi minat beli ulang masyarakat terhadap produk handphone. Value Added: Vol 8, No 2. Universitas Muhammadiyah Semarang

Ngoc, N. D. (2016). Business cooperation between indonesia and vietnam. Sampurasun eJournal Vol 02, No.01 June 2016

Oetomo, R. A., Rini N. (2012). Analisis pengaruh keragaman menu, persepsi harga dan lokasi terhadap minat beli ulang konsumen (studi pada restoran waroeng taman singosari semarang). Jurnal Manajemen Vol.2 No. 1 Januari 2012

Sreejesh, S. (2015). Consumers' perceived brand aspiration and its impact on intention to pay price premium: Moderating role of brand jealousy. Theoretical economics letters, 2015, 5, 273284.

Saidani, B., Samsul A. (2012). Pengaruh kualitas produk dan kualitas layanan terhadap kepuasan konsumen dan minat beli pada ranch market, Jurnal Riset
Manajemen Sains Indonesia (JRMSI), Vol. 3, No. 1, 2012.

Sariningsih, Y. (2017). Budaya Wirausaha KUBE. Jurnal Sampurasun Vol.3, Nomor 02, Desember 2017

Sugiyono. (2017). Metode penelitian kuantitatif, kualitatif, dan $R \& D$. Bandung: Alfabeta

Sudjianto, E. Y., \& Japarianto, E. (2017). Pengaruh dari perceived service quality, customer satisfaction dan customer loyalty dengan studi kasus hotel kartika graha malang. Jurnal Manajemen Pemasaran, Vol. 11, No. 2, Oktober 2017.

Sunyoto, D. (2016). Metodologi penelitian akuntansi. Bandung: PT Refika Aditama.

Thamrin, A., \& Francis, T. (2012). Manajemen pemasaran. Jakarta: Rajawali Pers.

Tjiptono, F., \& Chandra, G. 2016. Service quality \& satisfaction. Yogyakarta : Andi.

Widjiono, L. M., \& Japarianto, E. (2015). Analisa pengaruh self image congruity, retail service quality, dan customer perceived service quality terhadap repurchase intention dengan customer satisfaction sebagai variabel intervening di broadway barbershop surabaya. Jurnal Manajemen Pemasaran, Vol. 9, No. 1, April 2015.

\section{Biographies}

Dr. Ir. Bob Foster, M.M. born in North Sumatra (Pematang Siantar) in 1958, currently a functional position has been held as a lector since April 2009. The courses currently underway include strategic management, business introduction, marketing research, and marketing management seminars. The author has completed a bachelor's degree at the Bandung Institute of 
Technology in the field of electrical engineering in 1982, completing a master's program at Padjajaran University in the field of marketing management in 2002, then completing a doctoral program at Padjajaran University in 2005 with a field of business management. Since 2012 until 2018 the author has published 15 research titles, four titles of community service in 2015 and 2016, sixteen titles of scientific literature in journals, four titles of scientific articles presented at scientific seminars (oral presentatiton), five books from 2011 to 2014, the writer in 2013 also received an award as an outstanding community in West Java from the West Java Governor in 2013. 